\title{
ZVONY, ZVONICE A ZVONKOHRA NA VYŠEHRADĚ
}

\author{
BOŘIVOJ NECHVÁTAL
}

\author{
Miroslavu Plačkovi k 75. narozeninám
}

\begin{abstract}
Abstrakt: Prvni zpráva pisemných pramenů o vyšehradských zvonech se vztahuje k létům 1003-1004. Dalši zprávy o zvonech na Vyšehradě jsou mladšiho data. Zvon Patronus byl zhotoven v roce 1393 na náklad probošta Václava Králíka z Buřenic u př́ležitosti Milostivého léta. Byl to největši zvon své doby, ale do dnešní doby se nedochoval. Dále víme o zvonu Sv. Petr a Pavel z dílny Brikciho z Cymperka z roku 1584 a o druhém zvonu Marie z roku 1621 z dilny Baltazara Hoffmana. Podařilo se zjistit také půdorys zvonice a jeji vývojovou podobu z doby kolem 1610, před rokem 1678 a z let 1678-1903. Během prvni svètové války byly v roce 1916 zrekvírovány zvony z mladšiho období. To se opakovalo během druhé světové války roku 1942. Návrh na doplnění zvonů přišel až v roce 1993 od tehdejšiho probošta A. Doležala, kapitula však neměla finančni prostředky. Vyřešil to velkorysý dar dvou milionů korun od české emigrantky Mileny Jirat-Wasiutinski (1920-2008) žijicí v Kanadě. Zvony byly zhotoveny ve věhlasné zvonařské firmě Rudolf Perner, která původně působila v Českých Budějovicích, po roce 1945 byla však odsunuta do Pasova. Pracovala na Vyšehradě již dřive a roku 2001 provedla i doplnění zvonů a zvonkohru. Ta je řizena počítačovým programem s 50 melodiemi, které upravil a aranžoval varhaník Jaroslav Vodrážka. Melodie byly nastaveny na všedni a sváteční dny podle církevního roku a na zvonkohru se podařilo nahrát celou r̆adu skladeb Bedřicha Smetany a Antonína Dvořáka. Na realizaci přispělo i Hlavni město Praha a dalši sponzoři.
\end{abstract}

Klićcová slova: zvony - zvonkohra - rekvírování zvonů - sestava nových zvonů - bronzová zvonovina restituce.

\section{The bells, bell tower and chimes at Vyšehrad}

Abstract: The first mention of Vyšehrad bells in written sources is associated with the years 1003-1004. Further reports regarding the bells at Vyšehrad are more recent. The bell Patronus was made in 1393 and financed by the provost Václav Králik of Buřenice on the occasion of the Summer of Mercy festival. It was the largest bell of its time; unfortunately it has not survived. There is also information about the Sts. Peter and Paul bell made in the workshop of Brikci from Cymperk in 1584, and the Mary bell from 1621 from the workshop of Baltazar Hoffman. Archaeologists further determined the plan of the bell tower and its building form in the period around 1610, before 1678 and in the years 1678-1903. During the First World War in 1916, bells from the more recent periods were confiscated, and this also happened during the Second World War, in 1942. The proposal to replenish the bells only emerged in 1993 and came from the provost A. Doležal. However, the chapter did not have sufficient financial means. This problem was solved by a generous donation of two million crowns from the Czech emigrant Milena Jirat-Wasiutinski (1920-2008) living in Canada. The bells were manufactured by the renowned bell-making company Rudolf Perner which was originally active in České Budějovice but after the year 1945 relocated to Passau. The company had worked at Vyšehrad before, and in 2001 complemented the set of bells and the chimes. The chimes are controlled by a computer programme with 50 melodies, modified and arranged by the organist Jaroslav Vodrážka. The melodies are set for both ordinary and festive days following the church year. In addition, the chimes have been provided with numerous compositions by Bedřich Smetana and Antonín Dvorák. They were financed by the City of Prague and other sponsors.

Key words: bells - chimes - confiscation of bells - set of new bells - bronze bell metal-restitution.

Zvukovou atmosféru Vyšehradu, místa, které je spojováno s nejstaršími českými dějinami, vytvářejí dnes renesanční zvony a novodobá zvonkohra. První zpráva písemných pramenů o vyšehradských zvonech se vztahuje k době, kdy byly naše země na krátkou dobu obsazeny vojskem knížete a později krále z rodu Piastovců Boleslava Chrabrého (996/997-1025). Vyšehrad zůstal věrný knížeti Jaromírovi a nebyl dobyt. Zpráva saského kronikáře Dětmara Merseburského (Neškudla-Žytek edd. 2008, 149-150, 165-167) hovoří o zvonění zvonů na Vyšehradě, které bylo signálem k vyhnání 


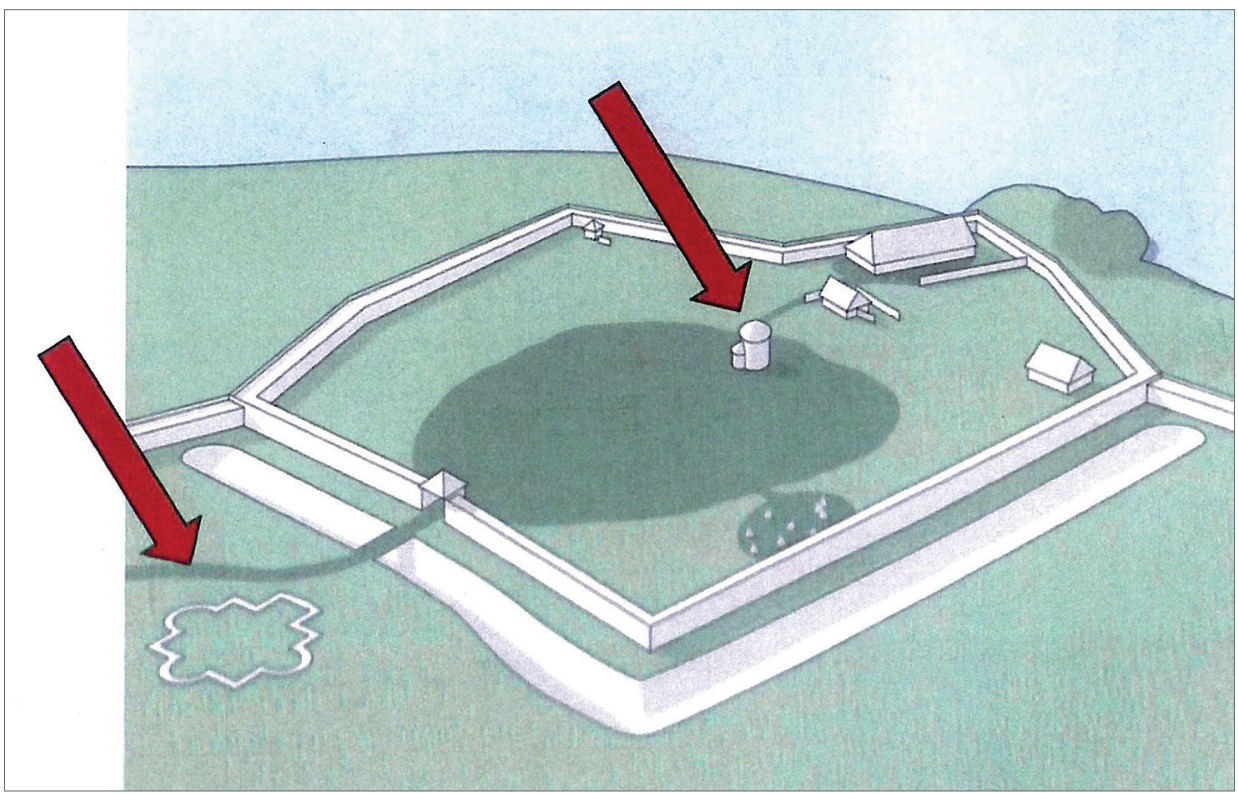

Obr. 1. Vyšehradská akropole okolo roku 1000 a lokalizace předrománské trikonchy s možnou polohou kaple sv. Jana Evangelisty. Autor L. Varadzin.

Abb. 1. Vyšehrader Akropolis um das Jahr 1000 und Lokalisierung des vorromanischen Trikonchos mit möglicher Lage der Johannes-Evangelista-Kapelle. Autor L. Varadzin.

Poláků z Prahy a z Čech. Období polské okupace trvalo od jara 1003 až do podzimu 1004 (FRB II, 52; Bretholz ed. 1923, 63; Krzemieńska 1986, 29-33). Dále se k roku 1179 zmiňuje Jarlochův letopis, že se na polích blízko Vyšehradu srazila vojska českého knížete Bedřicha (1178-1189) s vojsky Fridricha I. Barbarosy (1125/1126-1190), ,et concrepantribus undique hinc rubis, inde campanis“ za obecného hlomozu tu trub, onde zvonů (citováno podle Kybalová-Lunga-Vácha 2005, 255; FRB II, 475; k politické situaci českého státu Novotný 1912, 691-693 s odkazy na starší, dosud cennou literaturu, především práce V. V. Tomka). Odkud se tehdy přesně vyzvánělo, nelze sice spolehlivě rozhodnout, Vyšehrad je ovšem jedním z nejpravděpodobnějších míst (Žemlička 2007). Za důležitý považuji též údaj, na který upozornila J. Hásková (1975, 108; srov. též Krzemieńska 1970, 520), a to, že byl kníže Jaromír po nastolení knížetem na Pražském hradě provolán knížetem i na Vyšehradě. Z této skutečnosti lze usuzovat na více nežli jen na přijetí za pána věrnou družinou (Hlaváček 1992).

Již z nejstarší zprávy o zvonění zvonů na hradišti vyplývá existence nejméně jedné sakrální stavby na počátku 11. století. Zda to byla stavba sv. Jana Evangelisty, která je na základě pozdějších zpráv kladena do prostoru knížecí a královské akropole a měla být do 14. století rotundou (Nechvátal et al. 2009, 175; Moucha-Nechvátal-Varadzin 2014, 593-596), nebo tzv. trikoncha pod bazilikou sv. Vavřince, pokud byla vůbec dokončena (Nechvátal et al. 2009), nelze se za stavu současného poznání blíže vyjádřit.

Neznáme detailnější informace o zvonové výbavě románské baziliky před Karlovou přestavbou, před níž stála ještě stále její hlavní lod' i s postranními loděmi a dvěma věžemi - zvonicemi, které byly jistě vybaveny také zvony. K roku 1349 jsou písemně doloženy dvě věže - zvonice (campanilia) na bocích hlavní lodi, mezi nimiž byla románská krypta s tehdy nově zřízeným oltářem sv. Filipa a Jakuba (Tomek 1873, 16). Stavba Karla IV., započatá po roce 1369, byla halovým pětilodím bez věží, proto muselo být její osazení zvony řešeno samostatnou stavbou, pokud již neexistovala nějaká starší. $Z$ doby poněkud pozdější pocházel nejstarší známý zvon jménem Patronus. Byl zhotoven v roce 1393 na náklad probošta Václava Králíka z Buřenic u př́ležitosti 


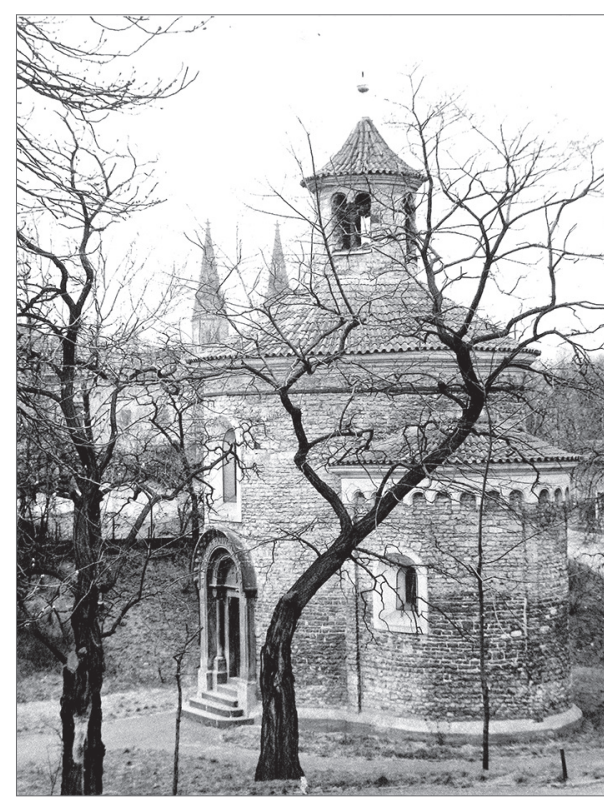

Obr. 2. Rotunda sv. Martina na Vyšehradě, okolo roku 1100. Foto A. Kleibl.

Abb. 2. Rotunde des HI. Martin auf dem Vyšehrad, um das Jahr 1100. Foto A. Kleibl.

Milostivého léta, vyhlášeného papežem Bonifácem IX. Ten tedy musel být podle Menclovy rekonstrukce předhusitského kostela zavěšen na samostatné zvonici současné s Karlovou stavbou nebo byl původně umístěn na jiné, starší stavbě. Tento zvon se nedochoval, byl ale ještě mnohem později mezi zvony kapitulního chrámu největší (Kybalová-Lunga-Vácha 2005, 256).

Vyšehrad byl ke konci roku 1420 podle kroniky Vavřince z Březové obléhán husity (Cermanová-Novotný-Soukup edd. 2014). Poškození Vyšehradu a kapitulního kostela v období husitské revoluce bylo současníky (Reitinger 2017) označováno za katastrofální, nemohlo ale být tak rozsáhlé, když zde byla roku 1423 provedena druhá pohřební

ceremonie Václava IV. a jeho otce Karla IV. před uložením jejich ostatků na Pražském hradě (Šmahel-Bobková 2012). Rovněž zachované nástěnné malby z doby předhusitské svědčí o tom, že se zachovala bohatá výzdoba interiéru (Nechvátal 2004, 99-104, srov. práci Z. Všetečkové).

Renesanční podoba kapitulního kostela sv. Petra a Pavla zůstala v hlavních stavebních rysech zachována až do 30 . let 18 . století. V té době došlo k jeho zásadní přestavbě. V době dokončování stavebních prací při přestavbě na barokní fortifikaci před rokem 1680 dochází k zásadní proměně Vyšehradu; stavební činnost započala i kapitula. Vedle výstavby barokní krypty v kapitulním kostele, kterou provedl Giovanni de Capauli, byla především postavena roku 1678 nová zvonice. Starší 
stavba „byla shledána sešlá“ (Ruffer 1861, 323-324). Nová stavba se musela řídit předpisy a omezením vojenského fortifikačního řádu. Byla prováděna za děkana J. V. Klimeše stavitelem Karlem Gadenciem z Casanovy. Neměla přesahovat výšku kapitulního kostela a musela být vůči baroknímu opevnění uměřená i svými proporcemi. Zachovala se společně s barokní stavbou kapitulního kostela až do roku 1903, kdy byla postupně zbořena (SÚA Praha, fond Stavební archiv kapituly vyšehradské, kart. 110, Scrinium LXV, fasc. 6).

Dnes již místo, kde zvonice stála, dovolují určit jen staré katastrální plány a fotografie. Původně měla zvonice čtvercový půdorys (ca $6 \times 7,5 \mathrm{~m}$ ) a byla vzdálena asi $7 \mathrm{~m}$ východně od závěru kostela, v ose severní boční lodi. Řadu důležitých údajů o její stavbě shromáždil historiograf kapituly V. Ruffer (1861, 323), který poznamenává: „(...) věž již dávno chatrná byla, - kdo a kdy ji stavěl, nenalezl jsem, takže Plocar na novou shromáždil penize, Veselanský dubové dřiví z Kladna kupoval. Klimeš dal roku 1678 stranou věž rozbourati a novou postaviti, zdali právě na tom samém mistě nebo ne, tvrditi nemohu (...). Vynaložil děkan $1222 \mathrm{zl} .58 \mathrm{kr}$. 3. den. V tom oučtu je také za správu a krytbu u kaple sv. Martina a za jiné malé správy vydání obsaženo. Dne 17. listopadu jest postavena na novou zvonici kostela Vyšehradského nová plechová báně pozlacena, obs. 1 str. 2 vert. Nad bání misto korouhve meč postř́ibrený a pres něj dva pozlacené klíce křǐzem postaveny." Při stavebním a archeologickém průzkumu bylo zjištěno, že zvonice stála na stejném místě jako předbarokní stavba, která je dobře do-

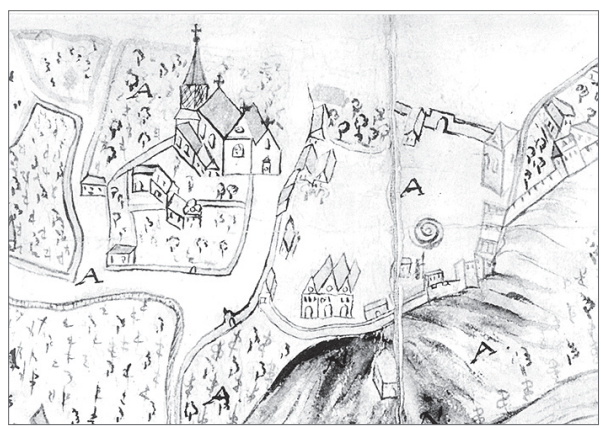

Obr. 5. Anonym, Vyobrazení Vyšehradu, ca 1606-1655, výřez.

Abb. 5. Anonym, Darstellung des Vyšehrad, ca. 1606-1655, Ausschnitt.

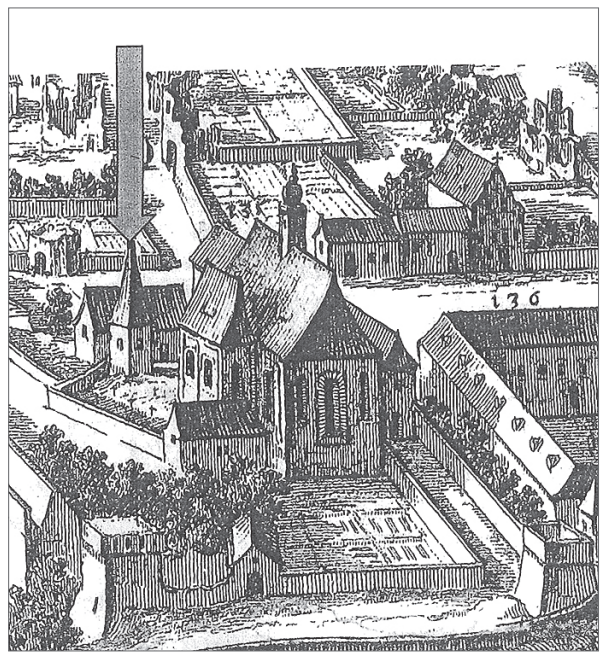

Obr. 6. F. van Ouden Allen, Vyobrazení Vyšehradu, před 1678, výř́ez.

Abb. 6. F. van Ouden Allen, Darstellung des Vyšehrad, vor 1678, Ausschnitt. ložena na Sadelerově prospektu z roku 1606 , kde má ještě dřevěnou nástavbu. Zvonice je také zachycena na objevené anonymní pohledové mapě z přelomu 16. a 17. století (Nechvátal 1973). Její otevřené podstřeší umožňovalo průhled na zvonovou stolici se dvěma zvony. Ty se dochovaly dodnes a jsou umístěny na novogotické stavbě kapitulního kostela. Jeden z nich, Sv. Petr a Pavel, pochází ze známé pražské dílny Brikcího z Cymperka (1535-1599) a byl ulit roku 1584 na náklady děkana Petra Lindy. Druhý, zvaný Marie, byl zhotoven roku 1621 v novoměstské dílně Baltazara Hoffmana, jehož činnost je také doložena v letech 1605-1617, mimo jiné i v nedalekém klášteře Na Slovanech. Třetím zvonem do počtu byl již zmíněný gotický Patronus. Ten byl ovšem nejspíše neznámo kdy přelit na nové zvony (Kybalová-Lunga-Vácha 2005, 64-71, 74-75, 256-257).

Barokní zvonice nahradila starší stavbu renesanční, která měla horní část střechy ze dřeva. V té době byla také přestavěna sanktuska, která dostala již nový barokní cibulový tvar. Detailním rozborem (Kašička-Nechvátal 1974) se podařilo zjistit, že zvony zachycené na zvonici na renesančních prospektech jsou na stavbě, která pocházela ještě z předhusitského období (k problematice 


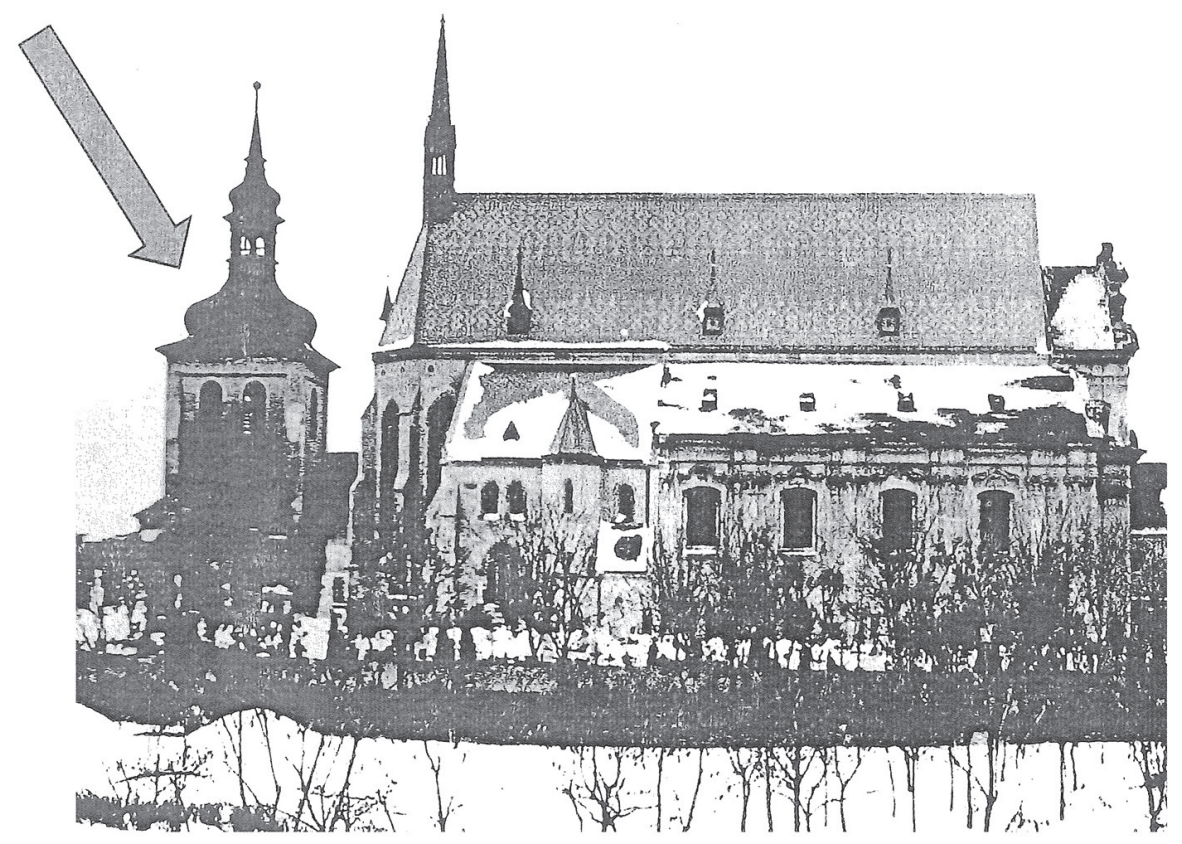

Obr. 7. Anonym, Fotografie Vyšehradu, před 1902.

Abb. 7. Anonym, Fotografie des Vyšehrad, vor 1902.

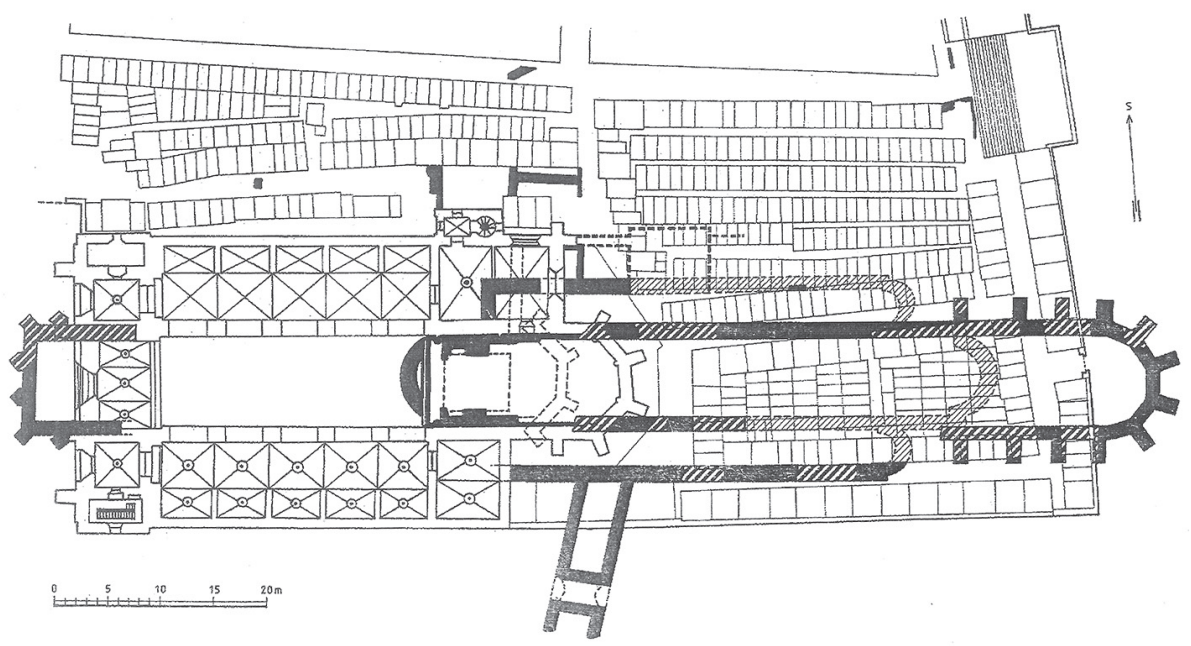

Obr. 8. Půdorys kapitulního chrámu se základy věže. Zdroj ARÚ AV ČR, Praha.

Abb. 8. Grundriss der Kapitelkirche mit Turmfundament. Quelle Archäologisches Institut der Akad. d. Wissenschaften der Tschechischen Republik, Prag. 
vyšehradských zvonů nejpodrobněji Kybalová 1958, 145-148, tab. XXXVIII a tab. XXXIX). Zvon Brikcího z Cymperka je považován za jeden $\mathrm{z}$ nejlepších zvonů $\mathrm{z}$ jeho dílny (Kybalová-Lunga-Vácha 2005, 71, 256-257). Vlastní základové zdivo zvonice a patrně i část nadzemních konstrukcí využila stavba barokní. Mědirytina Folperta van Ouden Allena z doby okolo roku 1680 zachycuje ještě zchátralou nástavbu, která byla nedlouho předtím stržena, a na dolní díl zvonice byl nasazen jehlan střechy $\mathrm{v}$ proporcích podobných střeše renesanční. Při archeologickém výzkumu v oblasti vyšehradského hřbitova v roce 1992 bylo zjištěno, že základové zdivo zvonice ve značně torzálním stavu respektovalo severní románskou lod' baziliky a bylo do ní částečně zavázáno (Nechvátal 2009).

Na novogotickou stavbu baziliky, přestavěné v letech 1885-1903 podle projektu Josefa Mockera, byly v roce 1902 zavěšeny do severní věže dva zvony Marie a Josef, vyrobené zvonařskou dílnou Rudolfa Pernera II. v Českých Budějovicích. Během první světové války, v roce 1916, však byly zrekvírovány. Věžními okny bylo tehdy vyhozeno osm zvonů (Lojka 2011).

Za druhé světové války, přesněji roku 1942, byly zabaveny další vyšehradské zvony $\mathrm{v}$ rámci odvodu barevných kovů nejen z kapitulního chrámu, ale i z dalších kostelíků a kaplí. Byly to především malé zvony o hmotnosti $59 \mathrm{~kg}$ a $38,5 \mathrm{~kg}$. Dva větší zvony o hmotnosti $2116 \mathrm{~kg}$ a $3055 \mathrm{~kg}$ bylo nutno rozbít ve zvonici, protože její okenní otvory byly menší než průměr zvonů. Po rekvizici zůstala severní věž bez zvonů. V jižní zbyl jen zvon Brikcího z Cymperka o hmotnosti ca 1200 kg a o průměru $125 \mathrm{~cm}$, tón $\mathrm{e}^{1}$, a zvon $\mathrm{z}$ dílny Baltazara Hoffmana (viz výše; Lojka 2011).

Návrh na doplnění zvonů kapitulního chrámu přišel v roce 1993 od tehdejšího probošta P. Antonína Doležala. Tohoto úkolu se zhostil ředitel Kapitulní kanceláře JUDr. Jan Kotous. Požádal zástupce zvonařské firmy

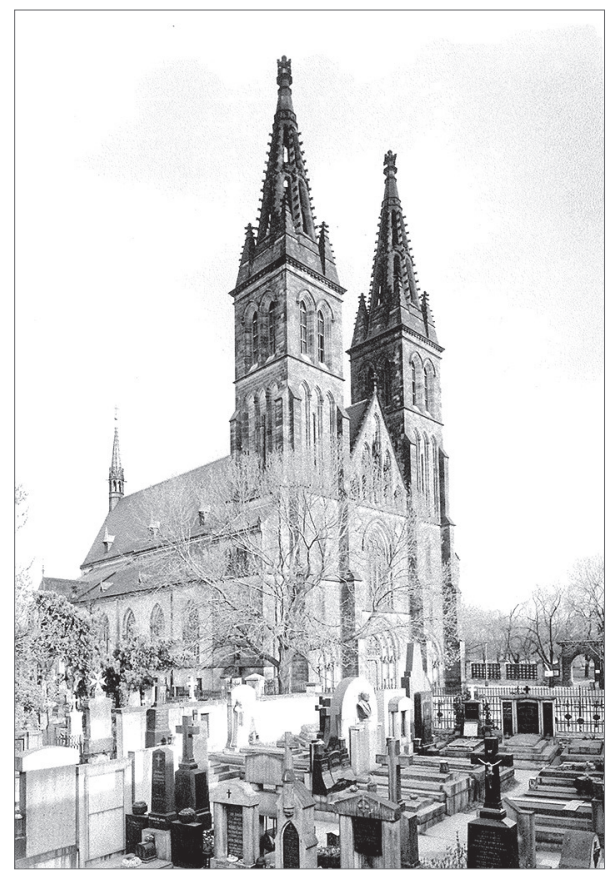

Obr. 9. Novogotické průčelí kapitulního chrámu, J. Mocker, F. Mikš. Foto A. Kleibl.

Abb. 9. Neugotische Fassade der Kapitelkirche, J. Mocker, F. Mikš. Foto A. Kleibl.
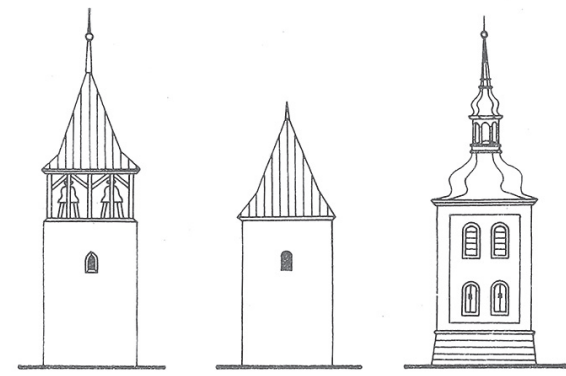

Obr. 10. Rekonstrukce vývojové podoby vyšehradské zvonice $\mathrm{z}$ doby kolem 1610 , před rokem 1678 a z let $1678-1903$. Kresba F. Kašička.

Abb. 10. Rekonstruktion der Entwicklungsformen des Vyšehrader Glockenturms aus der Zeit um 1610, vor dem Jahr 1678 und in den Jahren 1678-1903. Zeichnung F. Kašička.

\section{Perner MUDr. Martina Klouba z Českých}

Budějovic, který předložil několik návrhů a rozpočty. Šlo o tutéž firmu, která již pro kapitulu v minulosti zakázky realizovala (viz výše), po druhé světové válce však byla odsunuta a působí dodnes v Pasově. Byla objednána sada nových zvonů. Jako první byl osazen menší zvon v sanktusce nad kněžištěm kostela o hmotnosti $45 \mathrm{~kg}$ a průměru $45 \mathrm{~cm}$, tón $\mathrm{h}^{2}$. Dva historické zvony v jižní věži byly v roce 1997 opatřeny elektrickým pohonem. 
Finanční prostředky na doplnění zvonů na obou zvonicích však kapitula neměla. Vše nakonec vyřešil velkorysý dar Mileny Jirat-Wasiutinski (1920-2008), české krajanky z Kanady, která se počátkem 90. let minulého století navrátila z emigrace do vlasti. Po několika setkáních s představiteli kapituly se tato žena rozhodla zaplatit elektrické vytápění v kapitulním kostele. JUDr. J. Kotous jí totiž radil a pomáhal s restitucí rodinného majetku, kromě jiného především Dýhárny Orel ve Vysočanech. Když se M. Jirat-Wasiutinski dozvěděla o záměru kapituly doplnit zvony v bazilice, prohlásila, že pokud se restituce i následný prodej vysočanské továrny podaří, věnuje kapitule potřebnou částku na nové zvony. Restituce se zdařila v roce 2000 a opuštěná vysočanská továrna byla prodána. Hned následující den po prodeji převedla M. Jirat-Wasiutinski Vyšehradské kapitule dva miliony korun (Lojka 2011).

Proběhlo tedy další jednání s firmou Perner a byla objednána sada nových zvonů. Vlastník firmy Rudolf Perner navrhl, aby byla na Vyšehradě instalována i nová zvonkohra. Na jeho návrh kapitula přistoupila. Ve firemním archivu v Pasově byla nalezena dokumentace původních vyšehradských zvonů z roku 1902, tedy ještě z doby, kdy na stavbě kapitulního kostela působil probošt Mikuláš Karlach (1831-1911), třetí z vyšehradských vlasteneckých proboštů (Karlach 1905). Majitel firmy navrhl, aby byly odlity zvony stejného rozměru a hmotnosti. Nastal však technický problém. Původní zvony o průměru ca $160 \mathrm{~cm}$ byly vytaženy středem věží do již připravené zvonové stolice, později bylo postaveno dřevěné věžní schodiště a teprve poté byly zaklenuty klenby nad bočními vchody a zřízeny stropy v patře. Současné technické možnosti umožňují zvednout zvony jeřábem a vsunout je stávajícími okny, ta jsou však užší než průměr navrhovaných zvonů. Bylo by tedy nezbytně nutné zčásti vybourat kamenné okenní ostění, to však bylo nepřijatelné z pohledu Národního památkového ústavu. Navíc by to vyžadovalo značné náklady na stavební práce a na zřízení lešení uvnitř i vně jednotlivých věží. Po řadě jednání bylo tedy rozhodnuto, že budou zhotoveny zvony menšího průměru, aby mohly být vsunuty do věží bez dalších stavebních úprav, a v tónině, která by navazovala na tóny zvonů současných. Vlastní odlévání bylo realizováno ve zvonařské dílně v Pasově 27 . dubna 2001, a to ze $78 \%$ mědi a $22 \%$ cínu. Dílu požehnal vyšehradský kanovník Mons. Karel Havelka (Lojka 2011).

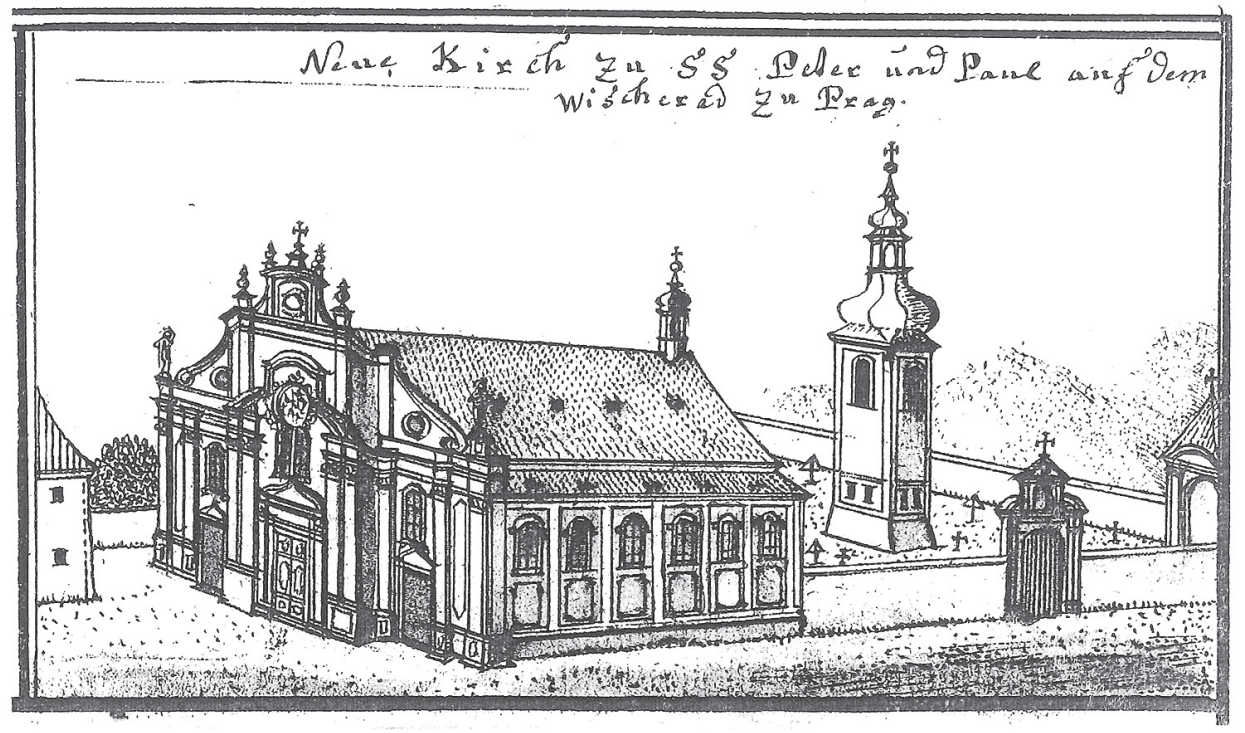

Obr. 11. Kostel sv. Petra a Pavla se zvonicí. Podle F. B. Vernera z roku 1712.

Abb. 11. St. Peter-und-Paul-Kirche mit Glockenturm. Nach F. B. Werner aus dem Jahr 1712. 


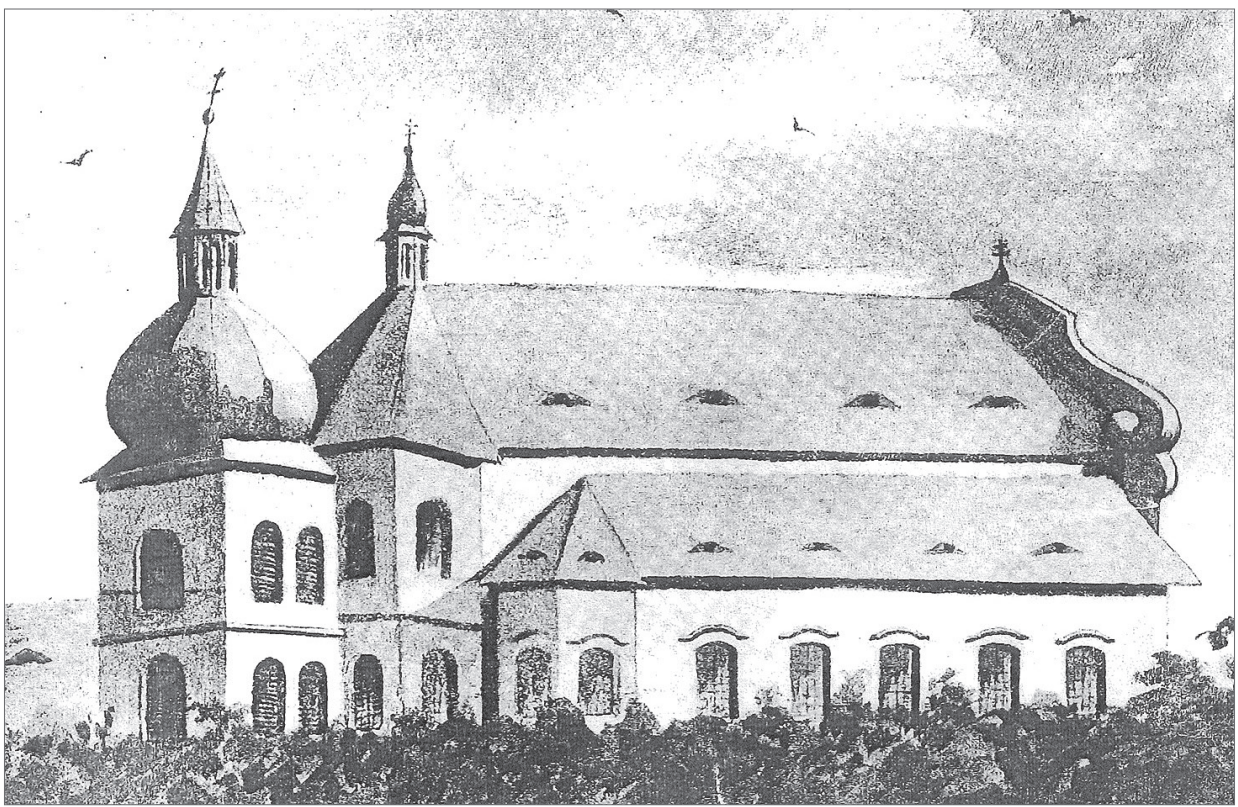

Obr. 12. Anonymní kresba severního pohledu na kapitulní kostel sv. Petra a Pavla se zvonicí z druhé poloviny 19. století.

Abb. 12. Anonyme Zeichnung der Nordansicht der Kapitelkirche St. Peter und Paul mit Glockenturm aus der zweiten Hälfte des 19. Jahrhunderts.

Pro zvonkohru na Vyšehradě byla dodána sestava osmnácti nových zvonů o celkové váze $2200 \mathrm{~kg}$ : čtyři velké se jmény Marie $\left(660 \mathrm{~kg}\right.$, tón a $\left.{ }^{1}\right)$, Josef $(290 \mathrm{~kg}$, tón cis²), Richard $(220 \mathrm{~kg})$, Václav $(190 \mathrm{~kg})$ a čtrnáct menších pro vlastní zvonkohru. Ty mají jména Anežka Česká, Zdislava, Jan Sarkander, Antonín Paduánský, Milena, Kliment, Jiř́, František, Jan Křtitel, Prokop. V současnosti je v obou kapitulních věžích novogotické stavby osazeno dvacet zvonů, další jsou osazeny v malé sanktusce. Během sobot, nedělí a církevních svátků lze slyšet šest pohyblivých houpacích zvonů, ve všední dny čtyři pohyblivé nové zvony, které jsou sladěny $\mathrm{v}$ akordu Salve Regina (tóny $\mathrm{a}^{+}+\mathrm{cis}^{2}+\mathrm{e}^{2}+\mathrm{fis}^{2}$ ). Stávající dřevěné zvonové stolice byly opraveny a byly přidány ztužující kovové konstrukce pro zavěšení dalších zvonů. Do věžních oken
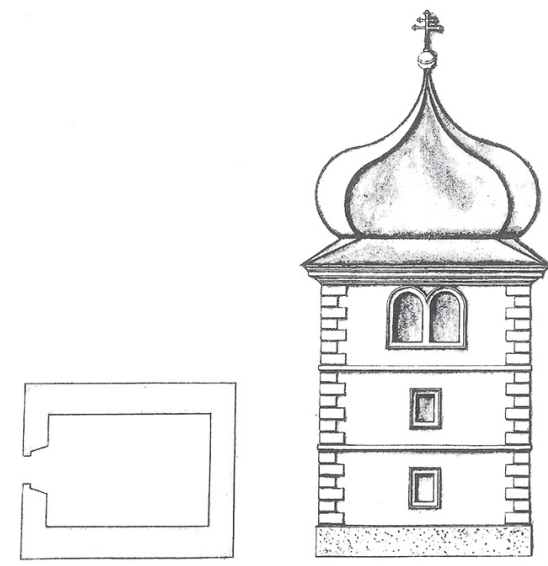

Obr. 13. Neuskutečněný návrh vyšehradské zvonice z konce 17. století.

Abb. 13. Nicht verwirklichter Entwurf des Vyšehrader Glockenturms aus dem 17. Jahrhundert.

byly opětovně vsazeny nové dřevěné žaluzie s lamelami, které byly nastaveny pod určitým úhlem, aby byl zvuk zvonkohry dobře a jasně slyšet jak dole pod věžemi, tak i v dáli. Okna byla opatřena sítěmi proti vniku ptactva. Při špatném počasí lze okna uzavřít zevnitř masivními okenicemi. Zvony jsou uváděny do pohybu elektrickým pohonem, který je počítačově naprogramován. Zvonkohra zní každou celou hodinu od 11 hodin dopoledne do 21 hodin večer. Vlastní zvonkohru 


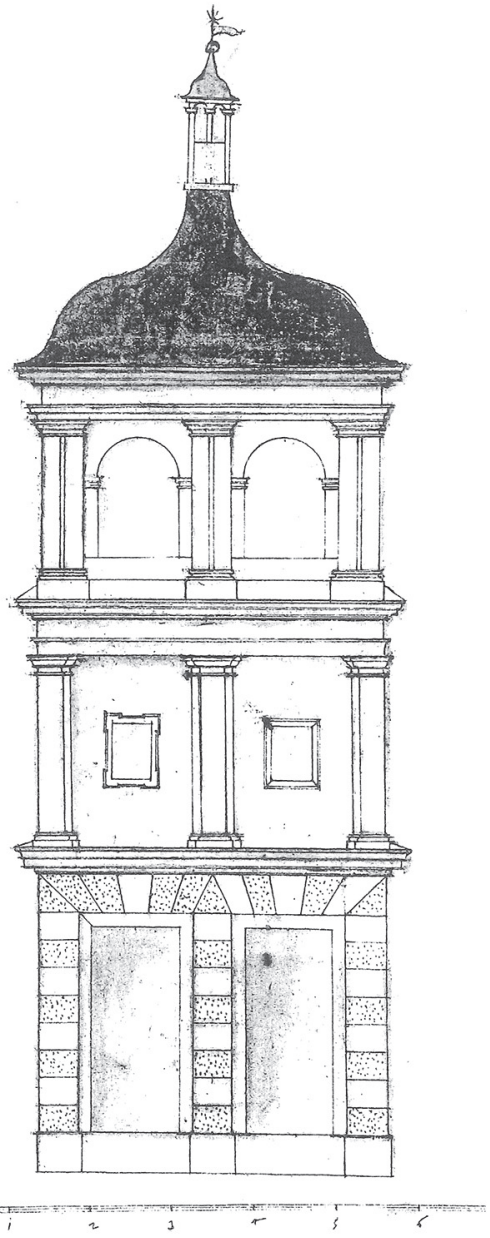

Obr. 14. Návrh stavby nové barokní zvonice (?).

Abb. 14. Entwurf für den Bau eines neuen barocken Glockenturms (?). 25. června. Slavnostní fanfáry zazněly v podání Hudby Hradní stráže a Policie ČR. Slavnostní bohoslužby za účasti mnoha hostů a věřících se účastnil i papežský nuncius Giovanni Coppa, a protože jeho působení v Čechách končilo a byl jmenován kanovníkem u baziliky sv. Petra ve Vatikáně, kapitula mu věnovala malou kopii obrazu Deštové madony. V závěru mše svaté probošt P. Antonín Doležal poděkoval dárkyni za finanční dar, který pokryl náklady na zvonkohru a doplnění zvonů. Během slavnostní bohoslužby byly zavěšeny tř̌i nové zvony. Čtvrtý a největší z nich, Marie, má základnu širší než šířku okenního otvoru, musel tedy být otočen o $180^{\circ}$ a vtažen do věže v nakloněné poloze. Před vlastním vtažením do věže poklepal několikrát kardinál Miroslav Vlk náhradním srdcem. Při zvedání zvonu Hudba Hradní stráže hrála chorál Svatý Václave (Lojka 2011).

Po určitém čase se v souvislosti s užíváním zvonů projevily technické problémy. Po „velkém zvonění, při němž bývá rozhoupáno všech šest velkých zvonů, docházelo k vibracím celého 


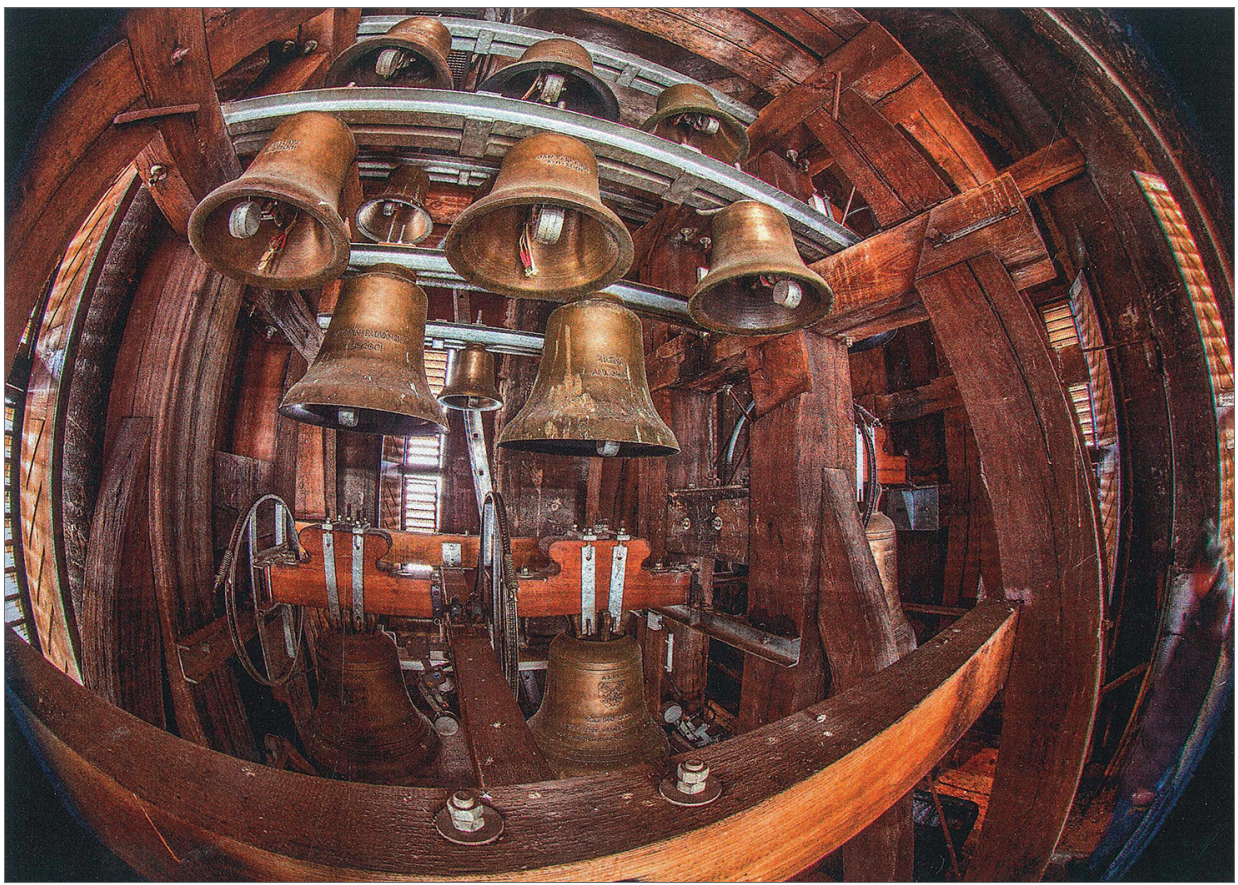

Obr. 15. Pohled na novou zvonkohru v severní věži kapitulního chrámu. Foto Roman Albrecht.

Abb. 15. Blick auf das neue Glockenspiel im Südturm der Kapitelkirche. Foto Roman Albrecht.

západního průčelí. Byli povoláni znalci z Kloknerova ústavu ČVUT v Praze. Bylo zjištěno, že dochází nejen k vibracím, ale i k vyklonění více než o $25 \mathrm{~mm}$. Zvonění velkými zvony bylo proto zastaveno, byly zhotoveny nové zvonové stolice, jeden zvon byl převěšen a velké zvony byly opatřeny protizávažími. Vrchol štítu byl staticky zajištěn před vibracemi a kmity a pružnými táhly ukotven ke střešní konstrukci dřevěného krovu nad hlavní lodí. Bylo také zjištěno, že při stavbě novogotického štítu byly některé konstrukce poddimenzovány a u některých použit nevhodný materiál. Základy jižní věže proto poklesly a objevily se další trhliny ve zdivu. Opatření ke zlepšení stavebního stavu si vyžádalo další finanční náklady. Na tyto opravy přispělo Hlavní město Praha a finanční prostředky byly získány i od sponzorů (Kybalová 1958; Kybalová-Lunga-Vácha 2005; Lojka 2011).

To je ve stručnosti historie vyšehradských zvonů, zvonic a zvonkohry, které vytvářejí neopakovatelnou zvukovou atmosféru této přední národní kulturní památky.

Př́spěvek vznikl v rámci projektu „Počátky Vyšehradu. Archeologie a vznik předního politického centra raného českého státu“ podpořeného Grantovou agenturou České republiky (18-16362 S).

\section{Prameny a literatura}

BRETHOLZ, B., ed., 1923: Die Chronik der Böhmen des Cosmas von Prag. In: MGH SRG NS II. Berlin. CDB II: Codex diplomaticus et epistolaris Regni Bohemiae II. (Friedrich, G., ed.). Pragae 1912.

CERMANOVÁ, P.-NOVOTNÝ, R.-SOUKUP, P., edd., 2014: Husitské století. Praha. 
ČUMLIVSKI, D., 2000: Vyšehradská kapitula od založení do poloviny 19. století. In: Vyšehrad historické podoby, 148-168. Praha.

FRB II: Fontes rerum Bohemicarum II. (Emler, J.-Tomek, V. V., edd.). Praha 1874.

HÁSKOVÁ, J., 1975: Vyšehradská mincovna na přelomu 10. a 11. století, SbNM A XXIV, 105-160.

HLAVÁČEK, I., 1992: Z dějin vyšehradské kapitulní knihovny ve stř̌edověku. In: Královský Vyšehrad. Sborník příspěvků k 900. výročí úmrtí prvního českého krále Vratislava II. (1061-1092), 69-81. Praha.

KARLACH, M., 1905: Paměti proboštů vyšehradských z poslední doby a sice od roku 1781 až do roku 1905. Praha.

KAŠIČKA, F.-NECHVÁTAL, B., 1974: Stavební vývoj zaniklé vyšehradské zvonice, PRP 32, 26-32.

- 1985: Vyšehrad pohledem věků - Der Wyscherad im Blick der Jahrhunderte. Praha.

KREZEMIEŃSKA, B., 1986: Břetislav I. Praha.

- 1970: Krize českého státu na přelomu tisíciletí, ČsČH 18, 497-532.

KYBALOVÁ, L., 1958: Pražské zvony. Praha.

KYBALOVÁ, L.-LUNGA, R.-VÁCHA, P., 2005: Pražské zvony. Praha.

LOJKA, K., 2011: Zvony a zvonkohra v bazilice sv. Petra a Pavla na Vyšehradě. Rkp. ulož. v Královské kolegiátní kapitule sv. Petra a Pavla na Vyšehradě.

MOUCHA, V.-NECHVÁTAL, B.-VARADZIN, L. et al., 2014: Vyšehrad. Knížecí a královská akropole. Svědectví archeologie. Praha.

NECHVÁTAL, B., 1976: Vyšehrad. Praha.

- 2004: Kapitulní chrám sv. Petra a Pavla na Vyšehradě. Archeologický výzkum. Praha.

NECHVÁTAL, B. et al., 2009: Rotunda sv. Martina a bazilika sv. Vavřince na Vyšehradě. Archeologický výzkum. Praha.

NEŠKUDLA, B.-ŽYTEK, J., edd., 2008: Dětmar z Merseburku. Kronika. Praha.

REITINGER, L., 2017: Vratislav I. První král Čechů. Praha.

RUFFER, V., 1861: Historie Vyšehradská neb vypravování o hradu, kapitule a městu hory Vyšehradu u Prahy v království českém. Praha.

ŠMAHEL, F.-BOBKOVÁ, L., edd., 2012: Lucemburkové. Česká koruna uprostřed Evropy. Praha.

TOMEK, V. V, 1873: Registra decimarum papalium. Praha.

- 1855-1901: Dějepis města Prahy. Sv. I-XII. Praha.

- 1882-1906: Dějepis města Prahy. 2. vydání. Sv. I-VIII. Praha.

VŠETEČKOVÁ, Z., 2001: Gotické nástěnné malby v kostele sv. Petra a Pavla na Vyšehradě. In: Královský Vyšehrad 2. Sborník př́spěvků ke křestanskému miléniu a k posvěcení nových zvonů na kapitulním chrámu sv. Petra a Pavla, 133-153. Kostelní Vydří.

ŽEMLIČKA, J., 2007: Čechy v době knížecí. Druhé přepracované vydání. Praha.

\section{Zusammenfassung}

\section{Glocken, Glockentürme und Glockenspiel auf dem Vyšehrad}

\section{Miroslav Plaček zum 75. Geburtstag}

Renaissanceglocken und ein neuzeitliches Glockenspiel bilden die Klangatmosphäre des Vyšehrad, einem Ort, der mit der ältesten Geschichte Böhmens verbunden ist. Der erste Bericht schriftlicher Quellen über Vyšehrader Glocken bezieht sich auf die Jahre 1003-1004, als unser Land für kurze Zeit von der Armee des Herzogs und späteren Königs aus dem Geschlecht der Piasten Bolesław des Tapferen (996/997-1025) besetzt war. Der Bericht des sächsischen Chronisten Thietmar von Merseburg spricht von einem Glockengeläute auf dem Vyšehrad als Signal, die Polen aus Prag und Böhmen zu vertreiben.

Weitere Berichte über die Glocken auf dem Vyšehrad stammen erst aus einer viel jüngeren Zeit. Die Glocke Patronus wurde im Jahr 1393 auf Kosten von Propst Václav Králík aus Buřenice 
anlässlich eines Erlassjahres angefertigt. Es war die größte Glocke ihrer Zeit, die jedoch nicht bis in die heutige Zeit erhalten geblieben ist. Ferner wissen wir von der St. Peter und Paul genannten Glocke aus der Werkstatt von Brikcí aus Cymperk aus dem Jahr 1584 und von einer weiteren Glocke Maria aus dem Jahr 1621 aus der Werkstatt von Balthasar Hoffman. Es ist auch gelungen, den Grundriss eines Glockenturms und seine Entwicklungsformen in der Zeit um 1610, vor dem Jahr 1678 und in den Jahren 1678-1903 festzustellen.

Im Jahr 1993 machte der damalige Propst P. Antonín Doležal den Vorschlag, die Glocken der Kapitelkirche zu ergänzen. Diese Aufgabe wurde von dem Direktor der Kapitelkanzlei, Herrn JUDr. Jan Kotous wahrgenommen. Er wandte sich an den Vertreter der Glockengießerei Perner aus České Budějovice, an Herrn MUDr. Martin Kloub, der einige Entwürfe und Kostenvoranschläge vorlegte. Es handelte sich dabei um dieselbe Firma, die in der Vergangenheit bereits Aufträge für das Kapitel ausgeführt hatte, nach dem Zweiten Weltkrieg wurde sie jedoch vertrieben und ist bis heute in Passau tätig. Man gab einen Satz neuer Glocken in Auftrag. Als erste wurde eine kleinere Glocke im Sanktustürmchen über dem Chorraum der Kirche mit einem Gewicht von $45 \mathrm{~kg}$, einem Durchmesser von $45 \mathrm{~cm}$ und dem Ton $\mathrm{h}^{2}$ installiert. Zwei historische Glocken im Südturm wurden im Jahr 1997 mit einem elektrischen Antrieb ausgestattet.

Die Finanzmittel für die Nachrüstung der Glocken in beiden Glockentürmen hatte das Kapitel jedoch nicht. Alles wurde schließlich durch eine großzügige Schenkung von Milena Jirat-Wasiutinski (1920-2008), einer tschechischen Landsmännin in Kanada geklärt. Man verhandelte wieder mit der Firma Perner. Der Eigentümer der Firma Rudolf Perner machte den Vorschlag, auf dem Vyšehrad auch ein neues Glockenspiel zu installieren. Im Passauer Firmenarchiv fand man die Dokumentation der ursprünglichen Vyšehrader Glocken aus dem Jahr 1902, also noch aus der Zeit, als Propst Mikuláš Karlach (1831-1911), der dritte der patriotischen Vyšehrader Pröpste am Bau der Kapitelkirche gewirkt hatte. Der Besitzer der Firma schlug vor, Glocken mit denselben Maßen und demselben Gewicht zu gießen. Wegen technischer Probleme wurden letztendlich jedoch Glocken mit kleinerem Durchmesser und in einer Tonart angefertigt, die an die Töne der bestehenden Glöcken anknüpfen, damit sie ohne weitere bauliche Veränderungen in die Türme hineingeschoben werden konnten. Der eigentliche Guss der Glocken wurde am 27. April 2001 in der Passauer Werkstatt durchgeführt, und zwar in einer Legierung aus $78 \%$ Kupfer und $22 \%$ Zinn. Das Werk wurde von dem Vyšehrader Kanoniker Mons. Karel Havelka eingesegnet (Lojka 2011).

Für das Glockenspiel wurde ein Satz von 18 neuen Glocken mit einem Gesamtgewicht von $2200 \mathrm{~kg}$ auf den Vyšehrad geliefert: vier große mit den Namen Maria (660 kg, Ton a $)$, Josef (290 kg, Ton cis $\left.^{2}\right)$, Richard $(220 \mathrm{~kg})$, Wenzel $(190 \mathrm{~kg})$, und 14 kleinere für das eigentliche Glockenspiel. Diese tragen die Namen Agnes von Böhmen, Zdislava, Johannes Sarkander, Antonius von Padua, Milena, Clemens, Georg, Franziskus, Johannes der Täufer, Prokopios. Gegenwärtig sind beide Kapiteltürme des neugotischen Bauwerks mit insgesamt 20 Glocken bestückt, weitere sind im kleinen Sanktustürmchen installiert. An Samstagen, Sonntagen und kirchlichen Feiertagen kann man sechs bewegliche Schwingglocken hören, an Werktagen vier bewegliche neue Glocken, die im Akkord des Antiphons Salve Regina (Töne $\mathrm{a}^{1}+\mathrm{cis}^{2}+\mathrm{e}^{2}+\mathrm{fis}^{2}$ ) gestimmt sind. Das Glockenspiel erklingt jede volle Stunde ab 11 Uhr vormittags bis $21 \mathrm{Uhr}$ abends. Das eigentliche Glockenspiel wird durch einen computergesteuerten elektromagnetischen Hammer zum Erklingen gebracht. Im Computer ist ein Programm mit 50 Melodien installiert, das von dem Organisten Jaroslav Vodrážka (in der eigenen chromatischen Tonleiter $\mathrm{d}^{2}-\mathrm{dis}^{2}-\mathrm{e}^{2}-\mathrm{f}^{2}-\mathrm{fis}^{2}-\mathrm{g}^{2}-\mathrm{gis}^{2}-\mathrm{a}^{2}-\mathrm{ais}^{2}-\mathrm{h}^{2}-\mathrm{c}^{3}-\mathrm{cis}^{3}$ ) bearbeitet und arrangiert wurde. Ferner kann eine Klaviatur an das Glockenspiel angeschlossen werden, auf der von Hand eine beliebige Melodie im gegebenen Tonumfang gespielt werden kann. Die großzügige und spendable Donatorin Milena Jirátová-Vasiutinski, die mit ihrer großzügigen Schenkung das Glockespiel möglich machte, hatte die einzige Bitte, dass an ihrem Namenstag (24. 1.) und ihrem Geburtstag (13. 4.) am Vorabend ihre Lieblingsweise Dobrú noc, má milá (Gute Nacht, du, mein Lieb, gute Nacht) erklingt. Sie wollte völlig anonym bleiben, was jedoch nicht 
restlos gelang. Heute hat sie auf dem Vyšehrader Friedhof im Nordteil der Wiehlschen Arkaden in der Nähe der Kapitelkrypta ihre letzte Ruhestätte.

Am 29. Juni 2001 wurde das neue Glockenspiel und auch die neuen Glocken von Kardinal Miloslav Vlk und dem Primas von Böhmen am Feiertag der Patrone des Kapitels zu Peter und Paul geweiht.

Nach einer gewissen Zeit tauchten im Zusammenhang mit der Nutzung der Glocken technische Probleme auf. Nach dem ,großen Geläut", bei welchem alle sechs großen Glocken in Schwingung gebracht werden, kam es zu Vibrationen der gesamten Westfassade. Es wurden Gutachter vom Klokner-Institut der Tschechischen Technischen Universität in Prag hinzugezogen. Man hat festgestellt, dass es nicht nur zu Vibrationen kommt, sondern auch zu Schwankungen von über $25 \mathrm{~mm}$. Das Läuten der großen Glocken wurde deshalb eingestellt, man führte Sanierungsarbeiten des Gebäudes durch und passte die Unterbringung der Glocken an. Für diese Reparaturen steuerte die Hauptstadt Prag Zuschüsse bei, auch von Sponsoren erhielt man Finanzmittel. Die Vyšehrader Glocken und das Glockenspiel schaffen die einzigartige Klangatmosphäre dieses führenden nationalen Kulturdenkmals (Kybalová 1958; Kybalová-Lunga-Vácha 2005; Lojka 2011).

Der vorliegende Beitrag entstand im Rahmen des von der Förderagentur der Tschechischen Republik geförderten Projektes „Die Anfänge des Vyšehrad. Die Archäologie und die Entstehung eines führenden politischen Zentrums des frühen böhmischen Staates“(18-16362 S).

PhDr. Bořivoj Nechvátal, CSc., Archeologický ústav AV ČR Praha, v. v. i., výzkum Vyšehrad, Štulcova 4, 12000 Praha, Česká republika, tel. 224918 758,nechvatal@arup.cas.cz 
